\title{
Growth, Mortality and Yield-per-recruit of Nile Tilapia (Oreochromis niloticus) in Garmat Ali River, Iraq
}

\author{
Ayat N. Salman and Abdul-Razak M. Mohamed* \\ Department of Fisheries and Marine Resources, College of Agriculture \\ University of Basrah, Iraq \\ *Corresponding author's email: abdul19532001 [AT] yahoo.com
}

\begin{abstract}
The study was conducted to estimate the growth, mortality, recruitment and yield-per-recruit of Oreochromis niloticus from Garmat Ali River, Basrah, Iraq from October 2019 to September 2020. The population parameters were analyzed using the FAO-ICLARM stock assessment tool(FiSAT). A total of 2696O. niloticus ranged from 7.0 to $25.0 \mathrm{~cm}$ and the sizes $13.0-18.0 \mathrm{~cm}$ constituted $64.2 \%$ of the total catch. The length-weight relationship was $W=0.012 L^{3.109}$ suggesting that the species shows positive allometric growth. The growthparameters for the species were estimated as $L \propto=30.45 \mathrm{~cm}, K=0.45, t_{o}=-0.313$ and $\dot{O}=2.622$. The coefficients of total mortality (Z), natural mortality $(M)$ and fishing mortality $(F)$ were 3.26, 1.03 and 2.24, respectively. The exploitation rate for the species computed to be 0.69. Fish were recruited to the fishery at a mean size of $L_{50}=14.92 \mathrm{~cm}$. The peak of recruitment was $23.51 \%$ in June. The analysis of yield-per-recruit ( $Y / R$ ') indicates that stock is not being overfished since the present exploitation rate was below the biological target reference points $\left(E_{0.1}\right.$ and $\left.E_{m a x}\right)$. So, more yields could be achieved by reducing the mesh sizes of the nets for fishing the species.
\end{abstract}

Keywords-- Nile tilapia, growth and mortality, yield-per-recruit, Garmat Ali River, Iraq

\section{INTRODUCTION}

The Nile tilapia, Oreochromis niloticus (Linnaeus, 1758) is indigenous tocentral and north A frica and the middle east [1]. It has a broad natural distribution spanning from the upper Nile river southwards to the equat or and west to the Atlantic coast due to their environmental tolerance, successful reproductive strategies and trophic plasticity [2]. Zengeya et al. [3] reviewed the ecological tolerances of $O$. niloticus and stated it is tolerant to a wide range of temperatures $\left(8-42^{\circ} \mathrm{C}\right)$ but their natural temperature range is $13.5-33.0^{\circ} \mathrm{C}$ and is tolerant to brackis $h$ water of salinity ranges from $20-30 \%$. O. niloticus has rapid growth rate, high resistance disease, high fecundity, hatching throughout the year and parental care, make the species breeding increasingly important in the world [4]. Consequently, it has been widely introduced elsewhere, both in Africa and other continents, including tens of countries in Asia, Europe, North America, Central America and South America [5]. The globalproduction of tilapia was expected to continue to have risen by around 3-4 percent in 2018, reaching 6.3 million tones [6].

The population dynamics of $O$. niloticus have been assessed by several authors in different natural water bodies in the world over using FiSAT II (FAO-ICLARM Stock Assessment Tools) software such as Ahmed et al. [7] in the Kaptai Reservoir, Bangladesh; Njiru et al. [8] in the Kenyan portion of Lake Victoria; Novaes and Carvalho [9] in Barra Bonita Reservoir, Brazil; El-Bokhty and El-Far [10] in the Nile River, at Aswan region, Egypt; El-Kasheif et al. [11] in El-Bahr El-Faraouny Canal, Al-Minufiy a Province, Egypt; Yongo and Outa [12] in the open waters of Lake Victoria, Kenya; Alemu et al. [13] in Lake Hawassa, Ethiopia; Ana Mehak et al. [14] in Chashma Barrage, Pakistan and Shija et al. [15] in Lake Chamo, Ethiopia.

O. niloticus is exotic fish to Iraqi waters and it was first reported from the Shatt Al-Arab River in late 2013 [16]. Currently, the species is well established in different natural waters of Iraq [17-22]. The other two cichlid fish in Iraqi waters are redbelly tilapia, Coptodon zillii and blue tilapia, O. aureus [19]. These cichlids species have become widespread and prevalent in many Iraqi waters. They constituted $10.5 \%$ of fish assembly in Shatt Al-Arab River [20], 9.4\% of the fish as semblages in the East Hammar marsh [23], 21.3\% of fish in the middle part of the Shatt Al-Arab River [19], 32.6\% of fish in the lower reaches of Tigris River, north east of Basrah province [24], 21.9\% of fish structure in the Al-Swab River, a tributary of the Shatt Al-Arab River [25], 32.3\% of fish as semblage in Shatt Al-Arab River at Abu Al-Khasib dis trict [21], and 38.5\% of fish fauna in the Al-Kahlaa River, a tributary of the Tigris River, Mis san province [26].

Several studies have been discussed the serious threat of invaded fish species on the stability of ecosystems, and the impacts of cichlids introduced on native fish and their habitats were well documented [27]. Simoes Vitule et al. [28] 
mentioned that invasive fres hwater species are often the culprits driving biodiversity los s, either directly through biotic interactions, or indirectly by affecting the availability of es sential resources, facilitating the spread of infectious disease, or through hybridization with native taxa. Genner et al. [29] mentioned that O. niloticus was an important competitor and predator of native species, has potential to hybridize with indigenous Oreochromis species, and has been widely implicated in biodiversity loss globally. Moreover, Vicente and Fonseca-Alves [30] stated that the release of O. niloticus into nonnative aquatic ecosystems may result in competition for food and space, thereby damaging native species. Consequently, it became necessary to compiled information about the population s tatus of these invaded cichlids in Iraqi waters. Recently, the population dynamics and management of two cichlid species (C. zillii and O. aureus) in Shatt Al-Arab River have been studied by Mohamed and Abood (2020) [31], and the present study is a continuation of investigation on tilapia fish in Iraq.

The main objective of this study is to estimate growth parameters, mortality rates, probability of capture, recruitment pattern and yield per recruit of $O$. niloticus population in Garmat Ali river, north of Basrah, to provide basis for stock as sessment as well as information for proper management of this cichlid species.

\section{MATERIALS AND METHOD}

Fish samples were collected fromtwo sites on Garmat Ali river, north of Bas rah city within the coordinates $30^{\circ} 34$ to $30^{\circ} 35^{\circ} \mathrm{N}$ and $47^{\circ} 43^{-}$to $47^{\circ} 46^{\circ} \mathrm{E}$ (Fig. 1). The first site located near Al-Najeebia Brid ge opposite the Naval Academy and the second site in the upper river area before its confluence with the East Hammar marsh. The riveris affected by the tidal current of the Arabian Gulf through the Shatt Al-Arab River. The salinity of the river ranged from $1.2 \%$ in January to $9.9 \%$ in September. The predominant vegetation on the banks was Phragmites australis and Typha domingensis, whereas Ceratophyllum demersum was dominant in the deeper areas.

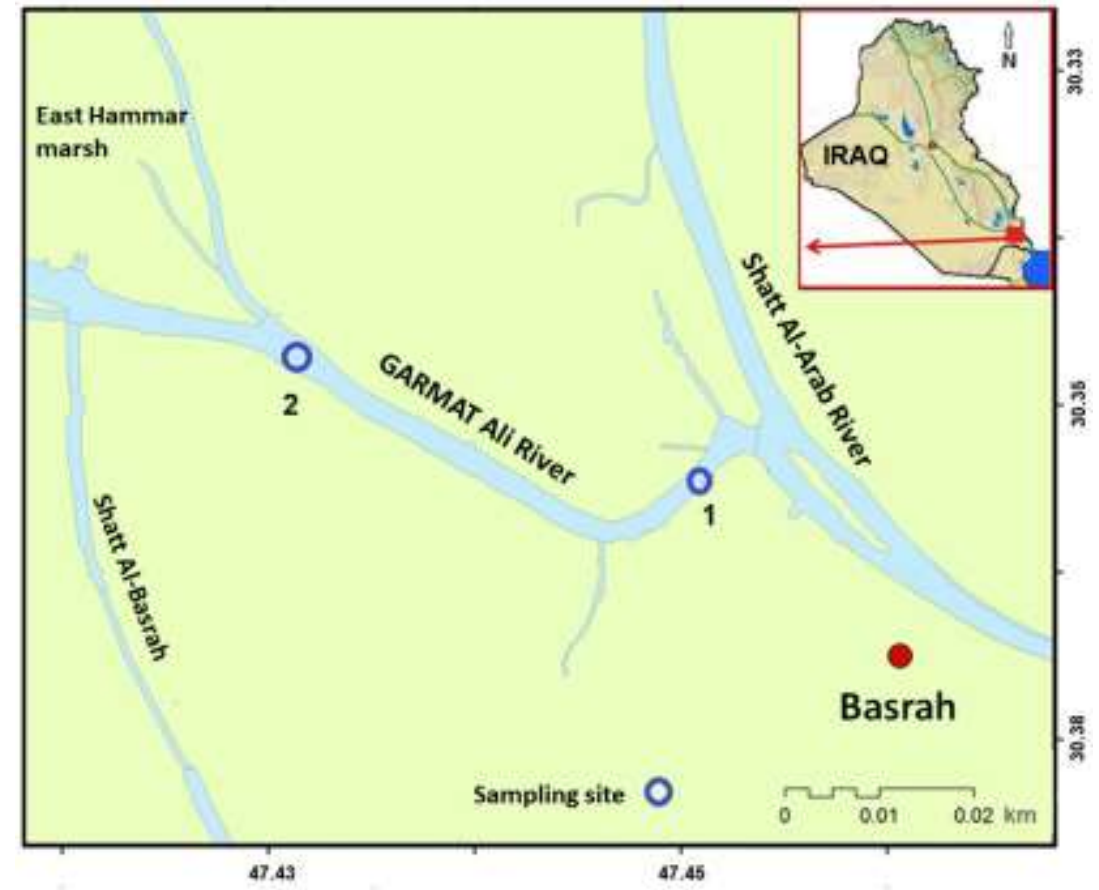

Figure 1: Map of Garmat Ali river with locations of study sites.

The fish were caught using gill nets of varying mesh size (200 m length with 15 to $35 \mathrm{~mm}$ mesh size), cast net ( $9 \mathrm{~m}$ diameter, with $15 \times 15 \mathrm{~mm}$, mesh size) and electro-fishing by generator en gine (providing 300-400V and 10A) from October 2019 to September 2020. The samples were immediately preserved in an icebox and transported to the laboratory for subsequent analy sis.

The total length was measured to the nearest $\mathrm{mm}$ for 2727 specimens of $O$. niloticus. The length frequency data were grouped into $1.0 \mathrm{~cm}$ class intervals, sequentially arranged according to a time series of 12 months, and stored in FiSAT II package [32] for subsequent analysis. A number of fish were measured with a precision of $1 \mathrm{~mm}$ and weight (W) with a precision of $0.5 \mathrm{~g}$. The length-weight relationship was establis hed on Microsoft Excel version $10 \mathrm{using}$ the formula of W= a $x L^{b}$ [33], where a the intercept and $b$ is the slope (growth coefficient). To test the $b$ value against the value of 3 , the Student's t-test was deployed to predict the type of growth [34]. 
The length data were analyzed using the FiSAT (FAOICLARM Stock Assessment Tools) after Gayanilo et al. [32] in the computer software package. The Electronic Length Frequency Analysis (ELEFAN 1 module in FiSAT II) was used to es timate the von Bertalanffy growth function (VBGF) through understanding the seasonal oscillation along with the estimation of the $\mathrm{L} \infty, \mathrm{K}$ and $\mathrm{R}_{\mathrm{n}}$. The predicted maximum length from extreme values was computed [35, 36]. The theoretical age at zero-length $\left(\mathrm{t}_{0}\right)$ was calculated using the empirical equation of Pauly [35]: $\log _{10}\left(-\mathrm{t}_{0}\right)=-0.3922-0.275 \log _{10} \mathrm{~L} \infty-1.0381 \log _{10} \mathrm{~K}$

Growth performance index $\left(\varnothing^{\prime}\right)$ was calculated according to the formula of Pauly and Munro [37]: $\emptyset^{\prime}=\log _{10} \mathrm{~K}+2 \log _{10} \mathrm{~L} \infty$.

The annual total mortality rate $(Z)$ was es timated by the length-converted catch curve analysis method of Pauly [35] incorporated in FiSAT package using the in put parameters Lo and K, and selecting the best points on the straight line of the right arm of the curve. The ins tantaneous rate of natural mortality $(\mathrm{M})$ was computed from the empirical equation of Pauly [38] considering the mean annual water temperature of the river as $26.3^{\circ} \mathrm{C}$ :

$$
\log _{10} \mathrm{M}=-0.0066-0.279 \log _{10} \mathrm{~L} \infty+0.6543 \log _{10} \mathrm{~K}+0.463 \log _{10} \mathrm{~T}
$$

The fishing mortality $(\mathrm{F})$ was obtained by the subtraction of $\mathrm{M}$ from $\mathrm{Z}$ and the exploitation rate (E) was calculated from the relationship: $E=F / Z$ [39]. The linearized catch curve used for es timating $Z$ was extrapolated backward to the points of the descending part of the length converted catch curve, a method incorporated into the FiSAT software package. The inbuilt logits method was used to derive values of the lengths at capture at probabilities of $0.25\left(\mathrm{~L}_{25}\right), 0.5$ ( $\left.\mathrm{L}_{50}\right)$ and $0.75\left(\mathrm{~L}_{75}\right)$.

The monthly recruitment pattern was reconstructed using the time series length-frequency data set and the growth parameters (Lo and K) as described in FiSAT software package. This routine reconstructs the recruitment pulse from a time series of length-frequency data onto a 1-year time scale [40].

The model of Beverton and Holt [41], as modified by Pauly and Soriano [42] was us ed to predict the relative yield per recruit $\left(\mathrm{Y}^{\prime} / \mathrm{R}\right)$ of the species to the fis heries. The calculations were done using the knife-edge method and the data of $\mathrm{L}_{c} / \mathrm{L}_{\infty}$ and $\mathrm{M} / \mathrm{K}$ values as described in FiSAT software package to es timate $\mathrm{E}_{0.1}, \mathrm{E}_{0.5}$ and $\mathrm{E}_{\mathrm{max}} . \mathrm{E}_{0.1}$ is a level of exploitation at which the marginal increase in yield per recruit reaches $1 / 10$ of the marginal increase computed at a very low value of $E$, $\mathrm{E}_{0.5}$ is the exploitation level as sociated with a $50 \%$ reduction of the biomass per recruit in the unexploited stock and $\mathrm{E}_{\max }$ is sus tainable exploitation level that produces the maximum yield. The biological target reference points, $\mathrm{E}_{0.1}$ and $\mathrm{E}_{\mathrm{max}}$ were compared with the current rate of exploitation (E) and used to determine the stat us of $O$. niloticus s tock at the river [43].

\section{RESULTS}

\subsection{Growth}

The overall length-frequency distribution of $O$. niloticus from monthly samples is shown in figure 2 . The sample composed of 2727 individuals ranging in total length from 7.0 to $25.0 \mathrm{~cm}$. The most frequent length groups percentage of O. niloticus were 23.1 and $52.8 \%$ corresponding to leng th groups $8.0-11.0$ and $14.0-17.0 \mathrm{~cm}$, res pectively. The population is dominated by middle-sized fish $13.0-18.0 \mathrm{~cm}$ cons tituted $66.1 \%$ of the total catch.

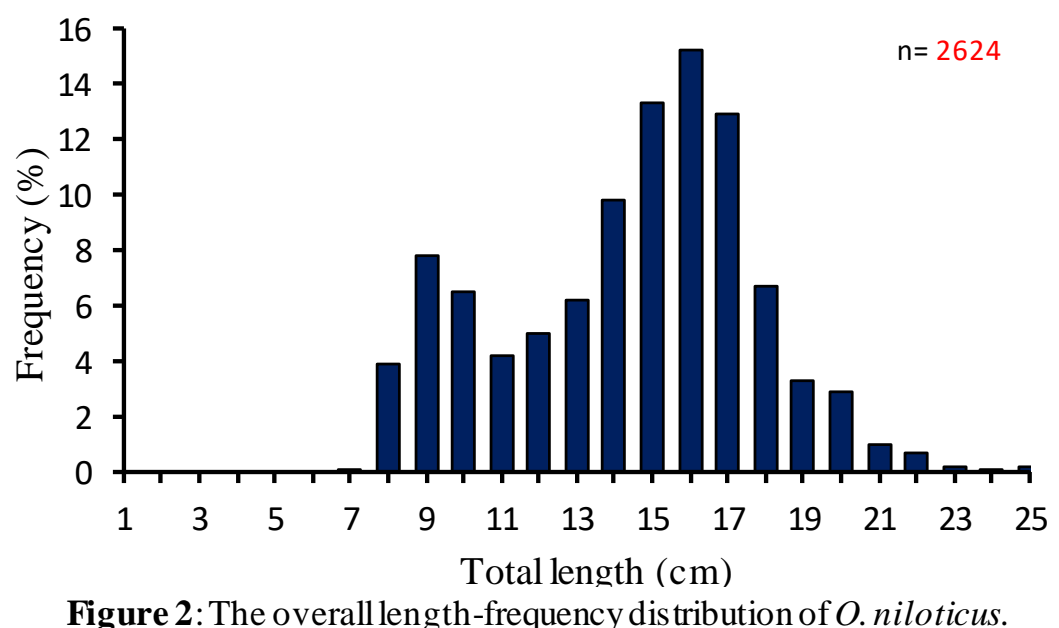

Length and weight measurements of 2050 specimens ranging from 8.0 to $25.5 \mathrm{~cm}$ in total length and weighing 8.0$325.0 \mathrm{~g}$ were used to describe the length-weight relationship of $O$. niloticus in the river (Fig. 3). The obtained equation was as follow: 


$$
\mathrm{W}=0.012 \mathrm{~L}^{3.109}, \quad \mathrm{r}^{2}=0.969
$$

The confidence limit of (b) was 3.085-3.133 and the t-test revealed that the regression was significantly different from $3(\mathrm{t}=9.02, \mathrm{P}<0.05)$, indicating positiveallometric growth.

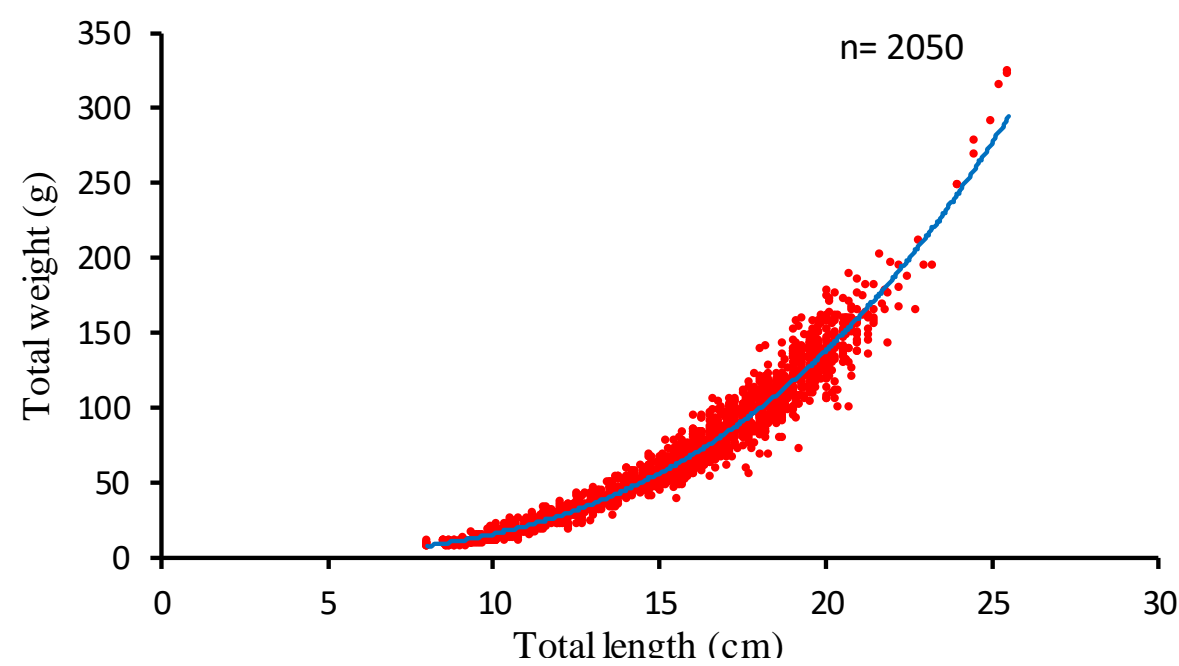

Figure 3: The length-weight relationship of $O$. niloticus.

The response surface $\left(R_{n}\right)$ analys is of the FiSAT package (Fig. 4) and the ELEFAN I routine were us ed to scan for the best estimates of the asymptotic length $\left(\mathrm{L}_{\infty}\right)$ and the growth constant $(\mathrm{K})$, based on the restructured form of the lengthfrequency data for $O$. niloticus (Fig. 5). The growth parameters for the species were estimated as $\mathrm{L} \infty=30.45 \mathrm{~cm}$ and $\mathrm{K}=$ 0.45 , while the estimated value of goodness of fit of model es timation $R_{n}=0.225$. The $t_{0}$ was calculated as -0.313 years. The growth performance index(ஜ́) was estimated as 2.622 .

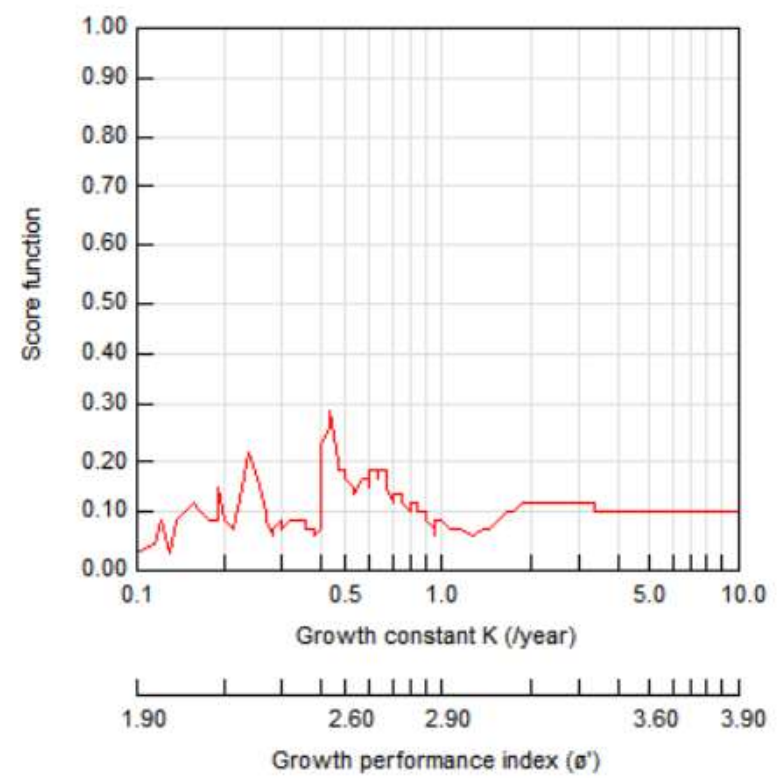

Figure 4: K-scan routines of $O$. niloticus. 


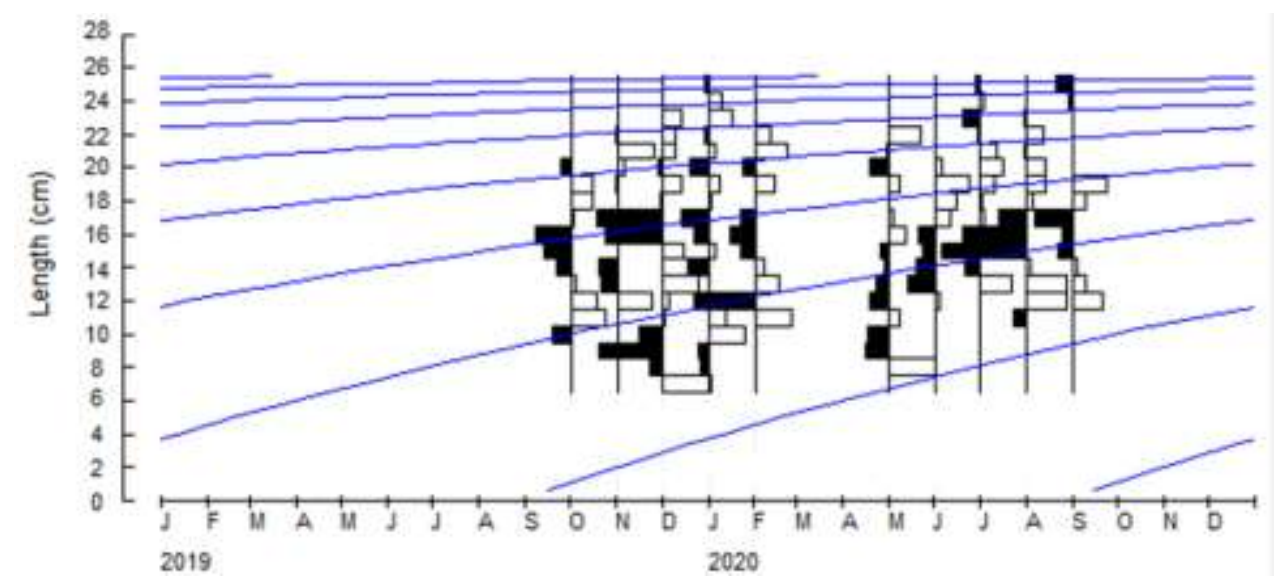

Figure 5: Restructured length-frequency distribution with growth curves superimposed using ELEFAN-1 for $O$. niloticus.

\subsection{Mortality and exploitation rates}

Figure 6 represents the catch curve utilized in the estimation of the total mortality (Z) of O. niloticus which was 3.26 ( $95 \%$ of confidence interval $(\mathrm{CI})$ of $Z=2.95-3.58$; standard deviation of the slope $=0.609 ; \mathrm{r}=-0.994$ ). The natural mortality rate $(\mathrm{M})$ was 1.03 , while the rate of fishing mortality $(\mathrm{F})$ was 2.24 . Therefore, the present exploitation rate (Epresent) was 0.69.

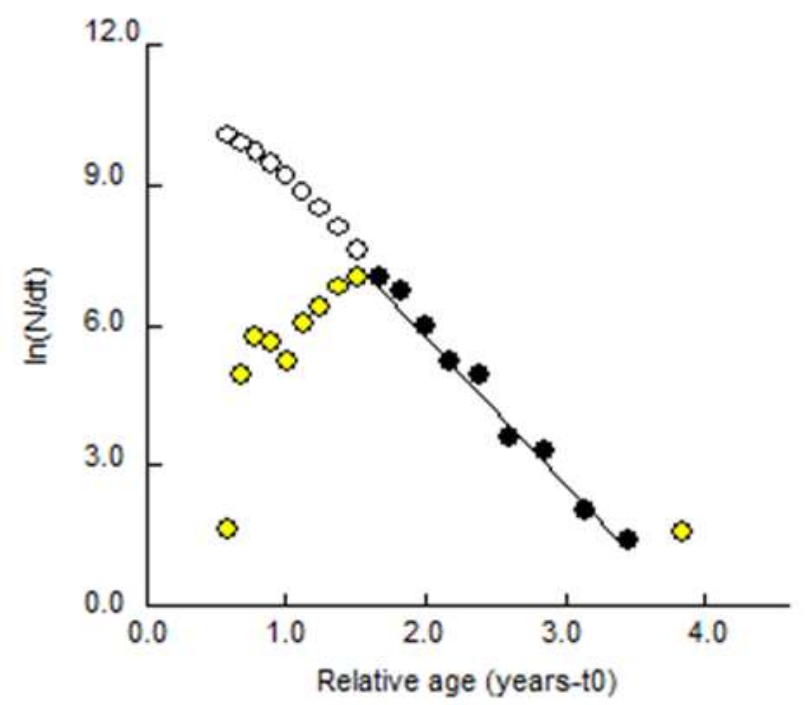

Figure 6: Length converted catch curves of O. niloticus.

\subsection{Probability of capture}

The probability of capture of $O$. niloticus was es timated as a component of the length converted catch curve analysis in FiSAT software (Fig. 7). The selection length of $25 \%$ or $\mathrm{L}_{25}$ was $13.64 \mathrm{~cm}, 50 \%$ or $\mathrm{L}_{50}$ was $14.92 \mathrm{~cm}$ and the $75 \%$ or $\mathrm{L}_{75}$ was $16.20 \mathrm{~cm}$. Hence, fish appeared to be recruited to the fis hery at a mean size of $\mathrm{L}_{50}=14.92 \mathrm{~cm}$. 


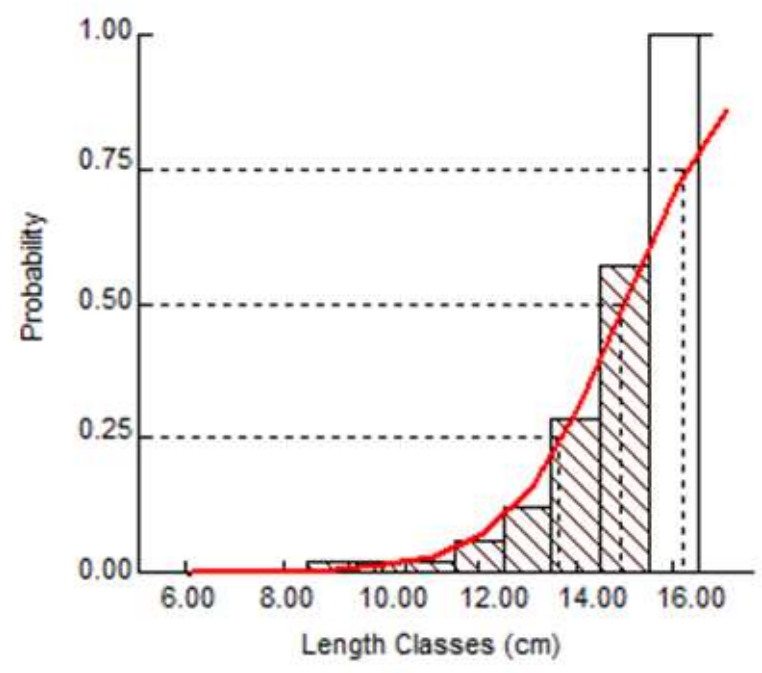

Figure 7: Probability of capture for O. niloticus.

\subsection{Recruitment}

It was found from the recruitment pattern that $O$. niloticus recruits almost throughout the year (Fig. 8). However, the main recruitment pulse was evident from April-July with a peak in June (23.51\%).

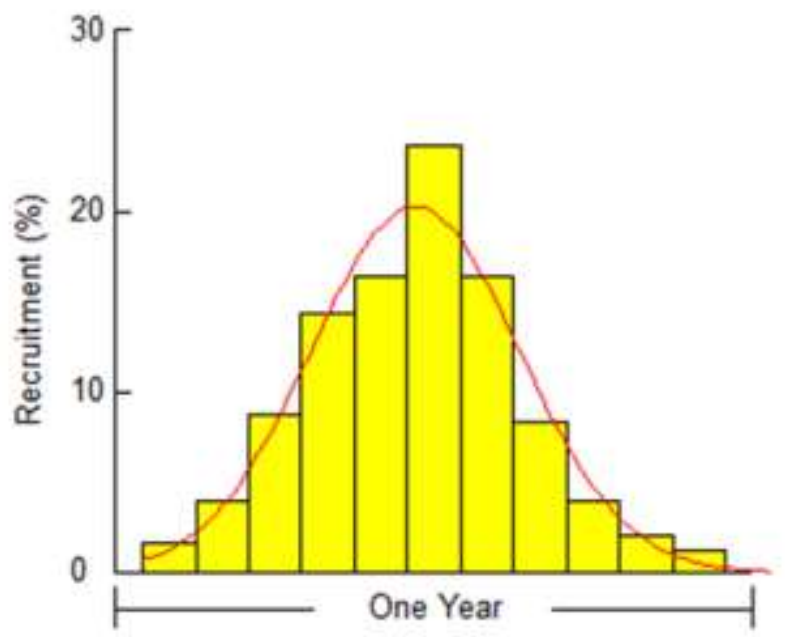

Figure 8: Recruitment pattern of $O$. niloticus.

\subsection{Yield per Recruit $\left(\mathbf{Y}^{\prime} / \mathbf{R}\right)$ and Biomass per $\operatorname{Recruit}\left(\mathbf{B}^{\prime} / \mathbf{R}\right)$}

The knife-edge selection routine in Beverton and Holt Y/R analyses incorporated in FiSAT package was adopted to predict the relative yield per recruit $\left(\mathrm{Y}^{\prime} / \mathrm{R}\right)$ of O. niloticus. Using the values of M/K (2.289) and Lc/Lo $(0.490)$ as derived from the previous analyses, the estimate values of $\mathrm{E}_{0.1}, \mathrm{E}_{0.5}$ and $\mathrm{E}_{\max }$ were $0.707,0.365$ and 0.824, res pectively (Fig. 9). It is clear that the present exploitation rate $\left(\mathrm{E}_{\text {present }}\right)$ is lower than the biological target reference points $\left(\mathrm{E}_{0.1}\right.$ and $\left.\mathrm{E}_{\mathrm{max}}\right)$ for the species. The relative yield-per-recruit $\left(\mathrm{Y}^{\prime} / \mathrm{R}\right)$ and relative biomas s-per-recruit ( $\left.\mathrm{B}^{\prime} / \mathrm{R}\right)$ were 0.024 and 0.220 , respectively. 


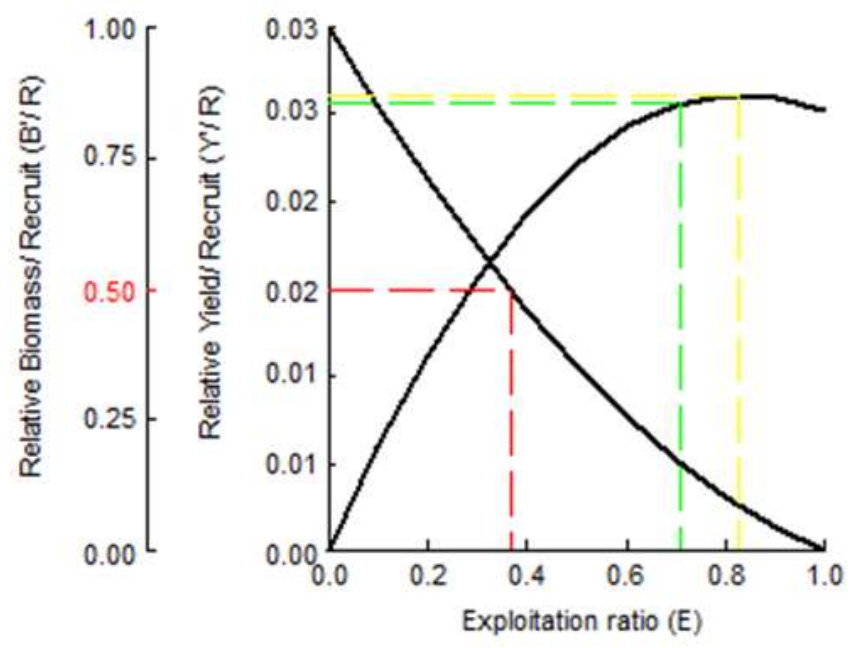

Figure 9: Relative yield per recruit $\left(\mathrm{Y}^{\prime} / \mathrm{R}\right)$ and biomas s per recruit $\left(\mathrm{B}^{\prime} / \mathrm{R}\right)$ analyses for O. niloticus.

\section{DISCUSSION}

The basic purpose of stock as sessment is to provide decision makers with the information necessary to make rational choices on the optimum level of exploitation of aquatic living resources such as fish [44]. The analysis of the length composition over the time of s ampling revealed that all the captured individuals of $O$. niloticus have an average total length ranging from 7.0 to $25.0 \mathrm{~cm}$. These sizes of fish were compared with those obtained by the various authors in different geographic localities (Table 1). It is clear that the length range of $O$. niloticus in the present study was comparable with those reported by other authors [46, 48, 49, 50, 52, 18, 54, 22, 58]. Conversely, other authors recorded higher values of length for this species in other waters $[7,46,9,50,52,11,54,55,56]$. These differences may partly be attributed to various factors including water condition, restricted habitats, food availability, population density, levels of intras pecific competition, fishing pressure and fishing gears [58-60].

Table (1): Comparative datafor the growth coefficient(b) for $O$. niloticus in different ecosystems.

\begin{tabular}{|l|c|c|l|}
\hline Authors & $\begin{array}{c}\text { Length range } \\
\text { (cm) }\end{array}$ & (b) & Region \\
\hline Ahmed et al. [7] & $15.0-53.0$ & 2.844 & Kaptai Reservoir, Bangladesh \\
\hline El-Bokhtym [45] & $6.9-27.5$ & 3.010 & Lake Manzala, Egypt \\
\hline Bwanika et al. [46] & $3.7-52.5$ & 3.117 & lakes Nabugabo and Wamala, Uganda \\
\hline Mahmoud and Mazrouh [47] & $9.5-25.5$ & 3.008 & Rosetta branch, Nile River, Egypt \\
\hline Shalloof and El-Far [48] & $12.0-22.0$ & 2.403 & Abu-Zaabal lakes, Egypt \\
\hline Novaes and Carvalho [9] & $11.0-31.2$ (SL) & 2.884 & Barra Bonita Reservoir, Brazil \\
\hline Hirpo [49] & $8.0-25.0$ & 2.690 & Lake Beseka, Ethiopia \\
\hline Hassan andEl-Kasheif [50] & $4.0-33.9$ & 2.792 & River Nile, Beni Suef, Egypt \\
\hline Mortuza and Al-Misned [51] & $6.9-27.3$ & 3.080 & Wadi Hanifah, Saudi Arabia \\
\hline Kembenya et al. [52] & $8.0-33.0$ & 3.080 & Lake Baringo, Kenya \\
\hline El-Kasheif et al. [11] & $4.8-33.6$ & 2.001 & El-Bahr El-Faraouny Canal, Egypt \\
\hline Khalifa [18] & $6.8-27.9$ & 2.010 & Tigris River, south Baghdad, Iraq \\
\hline Shalloof and El-Far [48] & $8.3-28.6$ & 2.726 & Rosetta branch, River Nile, Egypt \\
\cline { 2 - 4 } & $10.8-26.1$ & 3.063 & Damietta branch, RiverNile, Egypt \\
\hline Teame et al. [53] & $6.0-37.0$ & 2.917 & Tekeze Reservoir, Ethiopia \\
\hline Enawgaw and Lemma [54] & $2.5-30.9$ & 2.900 & Lake Tinishu Abaya, Ethiopia \\
\hline Cuadrado et al. [55] & $11.4-36.1$ & 3.138 & Lakes of Esperanza, Philippines \\
\hline Negaud [22] & $4.5-26.0$ & 3.210 & AL-Rumaitha River, Iraq \\
\hline Mohamed and Al-Wan [56] & $6.9-23.2$ & 3.077 & Garmat Ali river, Iraq \\
\hline Present study & $8.0-25.5$ & 3.109 & Garmat Ali river, Iraq \\
\hline
\end{tabular}

The

length-weight relationship is an important tool in fishery management. Principally, the relationship can be used for conversion of growth in length equations to growth in weight equations in the stock assessment models, forestimation of yield and biomass of a fish population, for the comparis on among geog raphical habitats and for predicting the general well- 
being of fish population $[33,34,61,60,62]$. The growth coefficient (b) of length-weight relationship is different among various geographic localities for the s ame species as presented in Table 2 . It is evident fromthe table that theb value of $O$. niloticus exhibited a different type of growth (isometric and negative or positive allometric) in various geographic locations, so it was ranged from 2.001 in the Pharaoh Sea Canal, Egypt and to 3.210 in Rumaitha River, Iraq. In the present study, $b>3$, indicated positive allometric pattern of growth in O. niloticus that means large fish samples have grown more in weight than in length and robustness of large-sized specimens; or large samples were in good nutritional environments at sampling time [63]. Riedel et al. [60] stated that this type of growth implies the fish becomes relatively stouter or deeperbodied as it increases in length. Several authors have als o reported positive allometric growth for O. niloticus fromvarious water bodies in the world $[45,46,51,52,48,55,22,561$. While other authors have been reported negative allometric growth for this species in other waters (Table 1). The length-weight relationship in fish can be affected by various factors such as habitat, season, stage of fish maturity, sex, food availability, stomach fullness, health, stress and sampling methodology $[34,64,63,55]$.

The results of growth parameters $\left(\mathrm{L} \infty, \mathrm{K}, \mathrm{t}_{\mathrm{o}}, \varnothing\right.$ and $\mathrm{L}_{\mathrm{c}}$ ) for $O$. niloticus in the current study and those reported from different geographic locations which were obtained by applying FiSAT II s oftware are shown in Table 2. It is clear that the values of these parameters obtained here are well within the range reported for this species in other studies. El-Bokhty and El-Far recorded the lowest value of Lo $(25.7 \mathrm{~cm})$ for O. niloticus in River Nile, Aswan, Egypt, whereas Ahmed et al. [7] found the highest value $(55.6 \mathrm{~cm})$ in Kaptai Reservoir, Bangladesh. Growth coefficient $(\mathrm{K})$ ranged from 0.29 [11] to 0.73 [10] and $t_{\mathrm{o}}$ from- -0.467 [15] to 0.09 [11]. The values of Ǿ for O. niloticus ranged from 2.61 [11] to 3.30 [8], and the estimate obtained in our study (2.62) compares with the lower end of this range. The estimated length at first capture $\left(\mathrm{L}_{c}\right)$ of $O$. niloticus was $15.5 \mathrm{~cm}$. This is also in line with the results of the length-frequency distribution in which $13-18 \mathrm{~cm}$ size groups were numerically dominant and constituted $67.2 \%$ of the population. This result was nearly close to those reported by El-Bokhty and El-Far [10] and El-Kasheif et al. [11], whereas lower than other es timates as shown in Table 2. These differences in the growth of this species in different locations could be attributed to several factors, such as the environmental conditions, habitat, availability of food, metabolic activity, reproductive activity, the genetic constitution of the individual, fis hing pressure and sampling method [58,36, 65, 66].

Table 2: Comparison of population parameters of $O$. niloticus in different ecosystems.

\begin{tabular}{|c|c|c|c|c|c|c|c|c|c|c|}
\hline Author & $\mathbf{L} \infty$ & $\mathbf{K}$ & $t_{0}$ & $\varnothing$ & $\mathbf{L}_{\mathbf{c}}$ & $\mathbf{Z}$ & M & $\mathbf{F}$ & $\mathbf{E}$ & Location \\
\hline Ahmed et al. [7] & 55.59 & 0.39 & - & 3.08 & 22.2 & 1.39 & 0.80 & 0.59 & 0.42 & $\begin{array}{l}\text { Kaptai Reservoir, } \\
\text { Bangladesh }\end{array}$ \\
\hline Njiru et al. [8] & 53.90 & 0.50 & - & 3.30 & - & 2.83 & 0.91 & 1.92 & 0.68 & $\begin{array}{l}\text { Lake Victoria, } \\
\text { Kenyan }\end{array}$ \\
\hline $\begin{array}{l}\text { Novaes and } \\
\text { Carvalho [9] }\end{array}$ & 33.60 & 0.63 & - & 2.85 & - & 2.81 & $\begin{array}{c}1 \\
.20 \\
\end{array}$ & 1.61 & 0.57 & $\begin{array}{l}\text { Barra Bonita } \\
\text { Reservoir, Brazil }\end{array}$ \\
\hline $\begin{array}{l}\text { El-Bokhty and El- } \\
\text { Far [10] }\end{array}$ & 25.73 & 0.73 & - & - & 14.1 & 3.64 & 1.44 & 2.20 & 0.60 & $\begin{array}{l}\text { River Nile, Aswan, } \\
\text { Egypt }\end{array}$ \\
\hline $\begin{array}{l}\text { El-Kasheif et al. } \\
\text { [11] }\end{array}$ & 37.27 & 0.29 & 0.090 & 2.61 & 14.2 & 1.15 & 0.65 & 0.49 & 0.43 & $\begin{array}{l}\text { El-Bahr El- } \\
\text { Faraouny Canal, } \\
\text { Egypt }\end{array}$ \\
\hline $\begin{array}{l}\text { Yongo and Outa } \\
\text { [12] }\end{array}$ & 46.24 & 0.69 & - & 3.14 & 20.3 & 2.18 & 1.14 & 1.05 & 0.46 & $\begin{array}{l}\text { Lake Victoria, } \\
\text { Kenya }\end{array}$ \\
\hline Alemu et al. [13] & 36.23 & 0.33 & - & - & - & 1.06 & 0.67 & 0.39 & 0.38 & $\begin{array}{l}\text { Lake Hawassa, } \\
\text { Ethiopia }\end{array}$ \\
\hline Shija et al. [15] & 55.00 & 0.37 & $0 . \overline{4} 67$ & - & - & 1.51 & 0.79 & 0.72 & 0.48 & $\begin{array}{l}\text { Lake Chamo, } \\
\text { Ethiopia }\end{array}$ \\
\hline Present study & 30.49 & 0.45 & $0 . \overline{313}$ & 2.62 & 14.9 & 3.26 & 1.03 & 2.24 & 0.69 & Garmat Ali river \\
\hline
\end{tabular}

The total mortality $(\mathrm{Z})$, natural mortality $(\mathrm{M})$, fis hing mortality $(\mathrm{F})$ rates and the exploitation rate (E) of $O$. niloticus comparing with those obtained by the various authors in different regions are given in Table 2 . The values of total and natural mortality rates obtained here are within the range observed in other populations of O. niloticus, where the lowest values of $\mathrm{Z}$ and $\mathrm{M}$ were 1.06 and 0.67 , respectively recorded by Alemu et al. [13] from Lake Hawassa, Ethiopia, and the highest values were 3.64 and 1.44, respectively obtained by El-Bokhty andEl-Far [10] from River Nile at As wan region, Egypt. On the other hand, the fis hing mortality and the exploitation rates of $O$. niloticus attained in this study were close to those obtained by Al-Bakhti and Al-Far [10] for the fishing rate of O. niloticus from the Nile River at Aswan region, and Ahmed et al. [7] for the exploitation rate for the same species fromLake Victoria, Ken ya, nevertheless both rates were higher than other estimates in Table 2. The optimumlevel of exploitation is 0.5 when fishing mortality is equal to natural 
one [39]. Hence, the the exploitation rate (E) in the present study (0.69) study indicates that the species is under high level of fishing pressure.

Recruitment pattern of $O$. niloticus species in this study reveals that the major pulse takes place in June. A similar trend was also observed in the study of Ahmed et al. [7] for the species in Kaptai Reservoir, Bangladesh.

The plot of relative yield per recruit $\left(\mathrm{Y}^{\prime} / \mathrm{R}\right)$ and biomass per recruit $\left(\mathrm{B}^{\prime} / \mathrm{R}\right)$ against exploitation rate (E) for O. niloticus was done using the knife-edge selection procedure and the data of $\mathrm{L}_{\mathrm{c}} / \mathrm{L}^{\circ}=0.490$ and $\mathrm{M} / \mathrm{K}=2.289$ to es timate the biological target reference points, $\mathrm{E}_{0.1}$ and $\mathrm{E}_{\mathrm{max}}$ [14]. The results of the analysis indicated that the present exploitation rate $\left(\mathrm{E}_{\text {presen }}=\right.$ $0.69)$ of O. niloticus was slightly lower than the optimum exploitation rate $\left(\mathrm{E}_{0.1}=0.707\right.$ and considerably lower than the maximum one $\left(\mathrm{E}_{\max }=0.824\right)$ which indicates that the stock of $O$. niloticus is underexploited in the study river. These findings have been noticed for O. niloticus stocks by other authors in different regions. Ahmed et al. [7] found that the values of $\mathrm{E}_{\text {present }}$ and $\mathrm{E}_{\max }$ were 0.42 and 0.63 , respectively in Kaptai Reservoir, Bangladesh. Novaes and Carvalho [9] pointed out that the values of $\mathrm{E}_{\text {present }}, \mathrm{E}_{0.1}$ and $\mathrm{E}_{\max }$ were $0.570,0.604$ and 0.776, respectively in Barra Bonita Reservoir, Brazil. El-Bokhty and El-Far [10] stated that $\mathrm{E}_{\text {presen }}=0.60, \mathrm{E}_{0.1}=0.757$ and $\mathrm{E}_{\max }=0.877$ for the species in River Nile at As wan region, Egypt. Also, El-Kasheif et al. [11] noted that the values of $\mathrm{E}_{\text {present, }} \mathrm{E}_{0.1}$ and $\mathrm{E}_{\max }$ were $0.43,0.51$ and 0.64, respectively for the s pecies in El-BahrEl-Faraouny Canal, Egypt. Mohamed and Abood [31] reported that the exploitation rates for $C$. zillii and $O$. aureus in the Shatt Al-Arab river were below the biological target reference points $\left(\mathrm{F}_{0.1}\right.$ and $\left.\mathrm{F}_{\max }\right)$, indicated that these species were als o not overexploited.

Based on present results, the invasive $O$. niloticus stock was underexploited, since did not attain the maximum sustainable yield, as there was a large difference between the leng th at first capture $\left(\mathrm{L}_{\mathrm{c}}\right)$ and the leng th at first maturity $\left(\mathrm{L}_{\mathrm{m}}\right)$, where Mohamed and Al-Wan [57] found that the length at first maturity $\left(\mathrm{L}_{\mathrm{m}}\right)$ of O. niloticus in Garmat Ali river ranged from 7.0 to $8.0 \mathrm{~cm}$. Hence, more yields could be obtained through a reasonable decrease in the size of the first capture without necessarily leading to overexploitation. This can be achieved by reducing the mesh sizes of the nets for fishing this species.

\section{REFERENCES}

[1] Boyd EC. "Farm-level is sues in aquaculturecertification: tilapia". Report commis sioned by WWF-US in 2004. Aubur University, Alabama, 2004.

[2] Lévêque C. 'Out of Africa: The success story of tilapias'. Environmental Biology of Fis hes, vol64, pp. 461-464, 2002.

[3] Zengeya TA, Robertson MP, Booth AJ, Chimimba CT. "Ecological niche modeling of the invasive potential of Nile tilapia Oreochromis niloticus in African river systems: concerns and implications for the conservation of indigenous congenerics". Biological Invasions, vol 15, pp. 1507-1521, 2013.

[4] FAO. "Cultured Aquatic Species Information Programme Oreochromis niloticus (Linnaeus, 1758)". http://www.fao.org/fis hery/culturedspecies/Oreochromis_niloticus/en. October 2020 version.

[5] Snoeks J, Freyhof J, Geelhand D, Hughes A. “Oreochromis niloticus. The IUCN Red List of Threatened Species 2018”. e.T166975A49922878. http://dx.doi.org/10.2305/IUCN.UK.2018.1.RLTS.T166975 A49922878.en.

[6] FAO. "GLOBEFISH Highlights-A quarterly update on world seafood Markets". January 2019 Issue. Food and Agriculture Organization of the United Nations, Rome, Italy, 2019.

[7] Ahmed KKU, Amin SMN, Haldar GC, Dewan S. "Population dynamics and stock as sessment of Oreochromisniloticus (Linnaeus) in the Kaptai Reservoir, Bangladesh”. Indian J. Fish., vol50(1), pp.47-52, 2003.

[8] Njiru M, Getabu A, Jembe T, Ngugi C, Owili M, van Knaap M. "Management of the Nile tilapia (Oreochromis niloticus (L.)) fishery in the Kenyan portion of Lake Victoria, in light of changes in its life history and ecology". Lakes and Reservoirs: Research and Management, vol 13, pp. 117-124, 2008.

[9] Novaes JLC, Carvalho ED. "Reproduction, food dynamics and exploitation level of Oreochromis niloticus (Perciformes: Cichlidae) from artis anal fisheries in Barra Bonita Reservoir, Brazil’. Revis ta de biologia tropical, vol 60(2), pp. 721-734, 2012.

[10] El-Bokhty EEB, El-Far AM. "Evaluation of Oreochromis niloticus and Tilapia zillii fisheries at Aswan region, River Nile, Egypt”. Egyptian Journal of Aquatic Biology and Fisheries, vol 18(3), pp. 79-89, 2014.

[11] El-Kasheif MA, Authman MMN, Al-Ghamdi FA, Ibrahim SA, El-Far AM. "Biological Aspects and Fisheries Management of Tilapia Fish Oreochromis niloticus (Linnaeus, 1758) in El-Bahr El-Faraouny Canal, Al- Minufiya Province, Egypt”. Journal of Fis heries and Aquatic Science, vol 10(6), pp. 405-444, 2015.

[12] Yongo E, Outa N. "Growth and population parameters of Nile tilapia, Oreochromis niloticus (L.) in the open waters of Lake Victoria, Kenya". Lakes and Reservoirs: Research and Management, vol21, pp. 375-379, 2016.

[13] Alemu Y, Snoeks J, Teklegiorgis Y, Nyssen J, Brendonck L. "As sessing sustainable fishing yields using length-based analytical models: A case study with Nile tilapia in Lake Hawass a (Ethiopia)". Journal of Fis heries and Livestock Production, vol5(4), pp. 1-10, 2017. 
[14] Ana Mehak YM, Mohsin M, Noman M, Nazir K. "Population dynamics of Nile Tilapia (Oreochromis niloticus) at Chas hma Barrage, Pakis tan”. Indian Journal of Geo Marine Sciences, vol46(01), pp. 206-210, 2017.

[15] Shija BS, Tesfaye G, Dadebo E. "Assessment of Maximum Sustainable Yield and Optimum Fis hing Effort for the Nile Tilapia (Oreochromis niloticus L.) in Lake Chamo, Ethiopia”. Journal of Agriculture and Environmental Sciences, vol 4(2), pp. 69-86, 2019.

[16] Al-Fais al AJ, Mutlak F.M. "First record of the Nile tilapia Oreochromis niloticus (Linnaeus, 1758), from the Shatt Al-Arab River, Southern Iraq”. Mesopotamia Journal of Marine Sciences, vol 29(1), pp. 45-50, 2014.

[17] Abulheni AKJ, Abbas LM. "First record of the Tilapia Oreochromis niloticus (Linnaeus, 1758) in Euphrates River at Al-Hindia Barrier, Middle of Iraq". Journal of the University of Kerbala. Speciel is sue, pp. 18-21, 2017.

[18] Khalifa SZ. "Ecological and biological of Nile tilapia Oreochromis niloticus and blue tilapia Oreochromis aureus from Tigris River, Southern Baghdad”. MSc. Thesis. University of Diyala, Iraq. 123p, 2017.

[19] Mohamed ARM, Abood AN. "Compositional change in fish assemblage structure in Shatt Al-Arab River, Iraq". Asian Journal of Applied Sciences, vol 5(5), pp. 944-958, 2017.

[20] Mohamed ARM, Hussein SA, Lazem LF. Spatiotemporal variability of fis h as semblage in the Shatt Al-Arab River, Iraq. Basrah Journal of Agricultural Sciences, vol 26(1), pp.43-59, 2013.

[21] Mohamed ARM, Hameed EK. "Impacts of s altwater intrusion on the fish assemblage in the middle part of Shatt AlArab River, Iraq". As ian Journal of Applied Sciences, vol 7(5), pp. 577-586, 2019.

[22] Negaud KZ. "Some biological aspects of Nile tilapia Oreochromis niloticus L. in AL-Rumaitha dis trict, Al-Muthanna province, s outhern Iraq". MSc. Thesis, University of Al-Muthanna, Iraq. 83p, 2019.

[23] AL-Shamary ACh. "Effect of alien species on assemblage fish in Shatt Al-Arab river and East Al-Hammar Marsh". Mesopotamia Environmental Journal, Special Issue A, pp. 18-32, 2016.

[24] Abdullah SA. "Diversity of fishes in the lower reaches of Tigris River, north east of Bas rah province, Southern Iraq". Basrah Journal of AgriculturalSciences, vol30(1), pp. 85-96, 2017.

[25] Abdullah AHJ, Abdullah SA, Al-Robayii OA. "Spatialand temporal pattern of sympatric fish as semblage in the AlSweib River South of Iraq". Proceedings of the 3rd Agricultural Scientific Conference 5-6 March 2018. The University of Kerbala, pp. 1-17, 2018.

[26] Abdullah SA, Abdullah AHJ, Ouda YW. "Diversity and status of fish fauna in the Al-Kahlaa River, in Missan Province-Iraq, with notes on environmental variables". EurAsian Journal of BioSciences, vol 13, pp. 1817-1824, 2019.

[27] Canonico GC, Artihington A, McCrary JK, Thieme ML. "The effects of introduced tilapias on native biodiversity". Aquatic Conservation: Marine and Freshwater Ecosystems, vol 15, pp. 463-483, 2005.

[28] Simoes Vitule JR, Freire CA, Simberloff D. "Introduction of non-native fres hwater fis can certainly be bad. Fish and Fisheries, vol10, pp. 98-108, 2009.

[29] Genner MJ, Connell E, Shechonge A, Smith A, Swanstrom J, Mzighani S, Mwijage A, Ngatunga BP, Turner GF. "Nile tilapia invades the Lake Malawi catchment". African Journal of Aquatic Science, vol 38, pp. 85-90, 2013.

[30] Vicente IST, Fonseca-Alves CE. "Impact of introduced Nile tilapia (Oreochromis niloticus) on non-native aquatic ecosystem". Pakistan Journal of Bioogical Sciences, vol 16(3), pp. 121-126, 2013.

[31] Mohamed ARM, Abood AN. "Population dynamics and management of two cichlid species in the Shatt Al-Arab River, Iraq". Journal of A pplied and Natural Science, vol 12(2), pp. 261-269, 2020.

[32] Gayanilo FCJr, Sparre P, Pauly D. "FAO-ICLARM Stock As sessment Tools II (FiSAT II)". Revis ed vers ion. Us er's guide. FAO Comp. Info. Ser. (Fis heries), vol 8, pp. 1-168, 2005.

[33] Le Cren ED. "The length-weight relationship and seasonal cycle in gonad weight and condition in the perch (Perca fluviatilis)". Journal Animal of Ecology, vol20, pp. 201-219, 1951.

[34] Ricker WE. “Computation and interpretation of biological statistics of fish populations". Bull. Fish. Res. Bd. Canada, vol 191, pp. 1-382, 1975.

[35] Pauly D. "Some simple methods for as sessment of tropical fish stocks. FAO Fish. Tech. Pap., 234: 52p, 1983.

[36] Sparre P, Venema SC. "Introduction to tropical fis h stock as sessment". Part 1. Manual. FAO fis heries technical paper. No. 306. 1, Rev. 2. FAO, Rome, Italy. 407 p, 1998.

[37] Pauly D, Munro JL. “Once more on the comparis on of growth in fish and invertebrates". ICLARM Fishbyte, vol2(1), pp. 21, 1984.

[38] Pauly D. "On the interrelationships between natural mortality, growth parameters and mean environmental temperature in 175 fish stocks". J. Cons. CIEM, vol39(3), pp. 175-192, 1980.

[39] Gulland JA. "Fish resources of the Ocean”. Fis hing News Books, Surrey, London, England. $255 p, 1971$.

[40] Pauly D."A review of the ELEFAN system for analysis of length-frequency data in fish and aquatic invertebrates". In: Pauly D, Morgan GR. (eds.). Length-based Methods in Fis heries Research, 13. ICLARM, 1987.

[41] Beverton RJH, Holt SJ. "Manual of methods for fish stock as sessment”. Part II. Fish. Biol. Tech. Pap., vol38, pp. 1067, 1966.

[42] Pauly D, Soriano ML. "Some practical extensions to Beverton and Holt's relative yield-per-recruit model”. In: Maclean JL, Dizon LB, Hosillo LV. (eds.). The First Asian Fisheries Forum, pp. 491-496, 1986.

[43] Cadima EL. "Fish stock assessment manual". FA OFis heries Technical Paper. No. 393. Rome, FAO. 161 , 2003. 
[44] Kebtieneh N, Alemu Y, Tesfa M. "Stock Assessment and Estimation of MaximumSustainable Yield for Tilapia Stock (Oreochromis niloticus) in Lake Hawas sa, Ethiopia". Agriculture, Forestry and Fis heries, vol 5(4), pp. 97-107, 2016.

[45] El-Bokhty EEB. "Assessment of family Cichlidae inhabiting Lake Manzala, Egypt". Egyptian Journal of Aquatic Biology and Fisheries, vol 10, pp. 85-106, 2006.

[46] Bwanika GN, Murie DJ, Chapman LJ. "Comparative age and growth of Nile tilapia (Oreochromis niloticus L.) in lakes Nabugabo and Wamala, Uganda”. Hydrobiologia, vol 589, pp. 287-301, 2007.

[47] Mahmoud MH, Mazrouh MM. "Biology and fisheries management of tilapia species in Rosetta branch of the Nile River, Egypt”. Egyptian Journal of Aquatic Research, vol34(3), pp. 272-285, 2008.

[48] Shalloof KA, El-Far AM. "Age, growth and fishery biology of cichlid spp. In Abu-Zaabal Lakes, Egypt”. Egyptian Journal Aquatic Biology and Fisheries, vol 13, pp. 101-116, 2009.

[49] Hirpo LA. "Reproductive biology of Oreochromis niloticus in Lake Beseka, Ethiopia". Journal of Cell and Animal Biology, vol7(9), pp. 116-120, 2013.

[50] Has san AA, El-Kasheif MA. "Age, growth and mortality of the cichlid fish Oreochromisniloticus (L.) from the River Nile at Beni Suef Governorate, Egypt”. Egyptian Journal Aquatic Biology and Fisheries, vol 17(4), pp. 1-12, 2013.

[51] Mortuza MG, Al-Misned FA. "Length-weight Relationships, condition factor and sex-ratio of Nile Tilapia, Oreochromis niloticus in Wadi Hanifah, Riyadh, Saudi Arabia”. World Journal of Zoology, vol 8(1), pp. 106-109, 2013.

[52] Kembenya EM, Ogellob EO, Githukiac CM, Aerad CN, Omondie R, Mungutif JM. "Seas onal changes of lengthweight relationship and condition factor of five fish species in Lake Baringo, Kenya". International Journal of Sciences: Basic and Applied Research, vol 14(2), pp. 130-140, 2014.

[53] Shalloof KA, El-Far AM. "Length-weight relationship and condition factor of some fishes from the River Nile in Egypt with special reference to four tilapia species". Egyptian Journal of Aquatic Biology and Fisheries, vol 21(2), pp.33-46, 2017.

[54] Teame T, Zebib H, Meresa, T. "Observations on the biology of Nile tilapia, Oreochromis niloticus L., in Tekeze Reservoir, Northern Ethiopia”. International Journal of Fis heries and Aquaculture, vol 10(7), pp. 86-94, 2018.

[55] Enawgaw Y, Lemma B. "Seasonality in the diet composition and ontogenetic dietary shifts of (Oreochromis niloticus L.) (Pisces: Cichlidae) in Lake Tinishu Abaya, Ethiopia". International Journal of Fisheries and Aquatic Research, vol3(1), pp. 49-59, 2018.

[56] Cuadrado JT, Lim DS, Alcontin RMS, Calang JL, Jumawan JC. “Species composition and length-weight relationship of twelve fish species in the two lakes of Esperanza, Agusan del Sur, Philippines". FishTaxa, vol 4(1), pp. 1-8, 2019.

[57] Mohamed ARM, Al-Wan SA. "Biological aspects of an invasive species of Oreochromis niloticus in the Garmat Ali River, Basrah, Iraq". Journal of Agriculture and Veterinary Science, vol 13(2), pp. 15-26, 2020.

[58] Nikolsky GV. "The ecology of fishes". Academic Press, London and New York, 352 p, 1963.

[59] Bwanika GN, Makanga B, Kizito Y, Chapman LJ, Balirwa J. "Observations on the biology of Nile tilapia, Oreochromis niloticus L., in two Ugandan crater lakes". African Journal of Ecology, vol42, pp. 93-101, 2004.

[60] Riedel R, Caskey LM, Hurlbert SH. "Length-weight relations and growth rates of dominant fishes of the Salton Sea: implications for predation by fish-eating birds". Lake and Reservoir Management, vol23, pp. 528-535, 2007.

[61] King MM. "Fis heries Biology, Assessment and Management”. 2nd ed. Blackwell Publishing Ltd, 400p, 2007.

[62] Froese R, Tsikliras AC, Stergiou KI. "Editorial note on weight length relations of fishes". Acta Ichthyol Piscat, vol 41, pp. 261-263, 2011.

[63] Froese R. (2006). "Cube law, condition factor and weight-length relationships: history, meta-analysis and recommendations". Journal of Applied Ichthyology, vol 22(4), pp. 241-253.

[64] Santos AFG, Santos LN, Araujo FG. "Water level influences on body condition of Geophagus brasiliensis (Perciformes: Cichlidae) in a Brazilian oligotrophic reservoir”. Neotropical Ichthyology, vol 2(3), pp. 151-156, 2004.

[65] W ootton RJ. "Growth: environmental effects". In:Farrell AP. (ed.). Encyclopedia of fish physiology: from genome to environment. Elsevier Science Publishing Co. Inc, USA, pp. 1629-1635, 2011.

[66] Panda D, Mohanty SK, Pattnaik AK, Das S, Karna SK. "Growth, mortality and stock status of mullets (Mugilidae) in Chilika Lake, India”. Lakes and Reservoirs, vol2018, pp. 1-13, 2018. 